\title{
Micro-Fabricated Thin-Film Fuel Cells for Portable Power Requirements
}

\author{
A. F. Jankowski, J. P. Hayes, R. T. Graff, J. D. Morse
}

This article was submitted to Spring Meeting of the Materials Research Society, San Francisco, CA., April 1-5, 2002

\section{March 21, 2002}

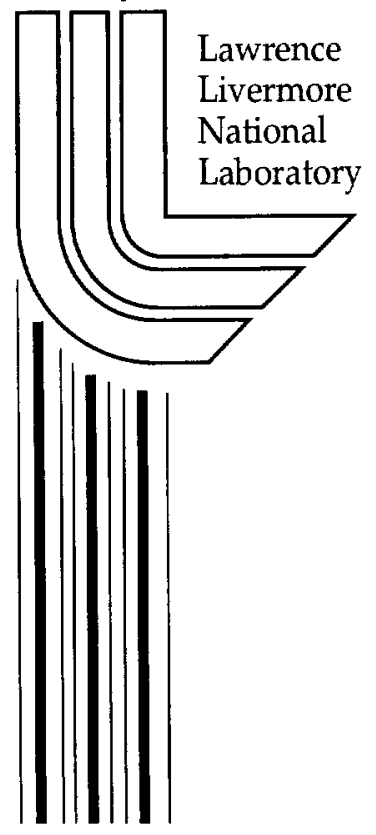




\section{DISCLAIMER}

This document was prepared as an account of work sponsored by an agency of the United States Government. Neither the United States Government nor the University of California nor any of their employees, makes any warranty, express or implied, or assumes any legal liability or responsibility for the accuracy, completeness, or usefulness of any information, apparatus, product, or process disclosed, or represents that its use would not infringe privately owned rights. Reference herein to any specific commercial product, process, or service by trade name, trademark, manufacturer, or otherwise, does not necessarily constitute or imply its endorsement, recommendation, or favoring by the United States Government or the University of California. The views and opinions of authors expressed herein do not necessarily state or reflect those of the United States Government or the University of California, and shall not be used for advertising or product endorsement purposes.

This is a preprint of a paper intended for publication in a journal or proceedings. Since changes may be made before publication, this preprint is made available with the understanding that it will not be cited or reproduced without the permission of the author.

This work was performed under the auspices of the United States Department of Energy by the University of California, Lawrence Livermore National Laboratory under contract No. W-7405-Eng-48.

This report has been reproduced directly from the best available copy.

Available electronically at http://www.doc.gov/bridge

Available for a processing fee to U.S. Department of Energy

And its contractors in paper from

U.S. Department of Energy

Office of Scientific and Technical Information

P.O. Box 62

Oak Ridge, TN 37831-0062

Telephone: (865) 576-8401

Facsimile: (865) 576-5728

E-mail: reports@adonis.osti.gov

Available for the sale to the public from

U.S. Department of Commerce

National Technical Information Service

5285 Port Royal Road

Springfield, VA 22161

Telephone: (800) 553-6847

Facsimile: (703) 605-6900

E-mail: orders@ntis.fedworld.gov

Online ordering: http://www.ntis.gov/ordering.htm

OR

Lawrence Livermore National Laboratory

Technical Information Department's Digital Library

http://www.llnl.gov/tid/Library.html 


\title{
Micro-Fabricated Thin-Film Fuel Cells for Portable Power Requirements
}

\author{
Alan F. Jankowski ${ }^{1}$, Jeffrey P. Hayes ${ }^{2}$, R. Tim Graff ${ }^{3}$, and Jeffrey D. Morse ${ }^{3}$ \\ Lawrence Livermore National Laboratory \\ ${ }^{1}$ Chemistry \& Materials Science, ${ }^{2}$ Mechanical Engineering, and ${ }^{3}$ Electrical Engineering \\ Livermore, CA 94551-9900, U.S.A.
}

\begin{abstract}
Fuel cells have gained renewed interest for applications in portable power since the energy is stored as a reservoir of fuel rather than as an integral part of the power source, as is the case with batteries. While miniaturized fuel cells have been demonstrated for the low power regime (1-20 Watts), numerous issues still must be resolved prior to deployment for applications as a replacement for batteries. As traditional fuel cell designs are scaled down in both power output and physical footprint, several issues impact the operation, efficiency, and overall performance of the fuel cell system. These issues include fuel storage, fuel delivery, system startup, peak power requirements, cell stacking, and thermal management. The combination of thin-film deposition and micro-machining materials offers potential advantages with respect to stack size and weight, flow field and manifold structures, fuel storage, and thermal management. The micro-fabrication technologies that enable material and fuel flexibility through a modular fuel cell platform will be described along with experimental results from both solid oxide and proton exchange membrane, thin-film fuel cells.
\end{abstract}

\section{INTRODUCTION}

The portable power source problem remains a critical issue for many consumer products as well as military objectives. While rechargeable batteries have become a hindrance in the utility of consumer portable electronics, present technologies are simply inadequate for the advanced military applications of remote reconnaissance and telemetry. Therefore, new power sources are required with performance criteria specific to the direct application. A lighter-weight and longer-lasting power source provides new functionality to applications that directly benefit the end user.

Miniature fuel cells have recently experienced renewed interest for applications in portable power generation. Energy is stored as a fuel rather than as an integrated component of the system. Thus, fuel cells can exhibit significantly higher energy densities than batteries depending upon the type of fuel being utilized. While this has been demonstrated for power portable applications in the range of $50-500 \mathrm{~W}$, effective scaling of fuel cell systems has not been commercially demonstrated for power applications in the range of 1-20 W. Present applications in this portable power range include consumer electronics as cell phones, laptop computers, video camcorders, and radios. New applications in portable power span the range of power consumption, from micro-power for long duration sensors and remote communication devices, to macro-power in the form of lighter weight sources for field use.

A miniature fuel-cell power source can be realized through an approach that combines thin film materials with micro-electro-mechanical system (MEMS) techniques.[1-5] In one idealized deployment, a micro-fabricated device (as shown in Fig. 1) consists of an integrated $\mu$-fuel cell power source, a computation-processing unit (CPU), a telecommunication transmitter-receiver (TX-RX), and a sensor. Based on either a solid-oxide (SOFC) or a proton-exchange membrane (PEM) electrolyte, the fuel cell device is monolithically integrated onto a manifold host structure (as shown in Fig. 2). The key structural components integral to the micro-fabricated fuel cell are the micro-machined manifold, the thermal and electrical insulating layers, the thin film electrodes, and the electrolyte layer. This architecture provides a scalable and portable fuel-cell power system for a broad range of applications that have power requirements in the range of 


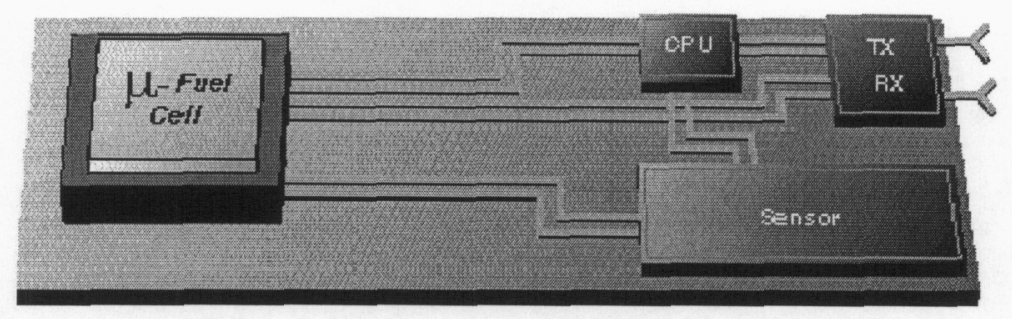

Figure 1. A micro-fabricated device is shown with an integrated $\mu$-fuel cell power source, a computation-processing unit (CPU), telecommunication transmitterreceiver (TX-RX), and sensor.

0.5-10 W. The MEMS approach offers a direct means to integrate the fuel cell stack with the required manifold and fuel delivery system. The MEMS integration provides a means to control the performance of the power source for specific applications.

\section{SAMPLE PREPARATION}

The use of thin film deposition with pattern and etching processes provides a direct path to the synthesis of a miniature fuel cell. The deposition sequence starts with the anode and concludes with the cathode. For a SOFC, synthesis of a dense and defect-free, thin electrolyte layer is accomplished by rf-sputter deposition of an oxide target as, e.g. $\left(\mathrm{Y}_{2} \mathrm{O}_{3}\right)_{6}\left(\mathrm{ZrO}_{2}\right)_{94} \cdot[1]$ For a PEM fuel cell, the electrolyte membrane can be a spin cast polymer as, e.g. Nafion ${ }^{\mathrm{TM}}$. Before detailing the electrode synthesis, the procedure is reviewed for preparing the micro-machined substrate platform.[2,5] A thin layer of silicon nitride is grown using a low pressure chemical vapor deposition process. The $0.2 \mu \mathrm{m}$ thick film is formed at $800^{\circ} \mathrm{C}$ using a $4: 1$ flow ratio of dichlorosilane and $\mathrm{NH}_{3}$ at a pressure of $33 \mathrm{~Pa}$. The backside of the substrate wafer is patterned by standard photolithographic techniques and etched to reveal individual windowed regions of silicon nitride with areas of $4-16 \mathrm{~mm}^{2}$ (as shown in Fig. 3a). The substrate is etched at a typical rate of $1 \mu \mathrm{m}-\mathrm{m}^{-1}$ using $44 \% \mathrm{KOH}$ at $85^{\circ} \mathrm{C}$. In a new improvement, the window size can be reduced to improve the rigidity of the structural support for the thin film fuel cell. A two-tiered deep anisotropic-etch procedure is developed that provides a silicon platform for the fuel cell base electrode with channels that are less than $5 \mu \mathrm{m}$ in width (as shown in Fig. 3b). A reactive ion etch rate of $0.42 \mu \mathrm{m}-\mathrm{m}^{-1}$ is typical during subsequent silicon nitride layer removal using 500 $\mathrm{W}$ of power with a $2.7 \mathrm{~Pa}$ pressure at a 1:2 flow ratio of $\mathrm{CHF}_{3}$ and $\mathrm{CF}_{4}$.

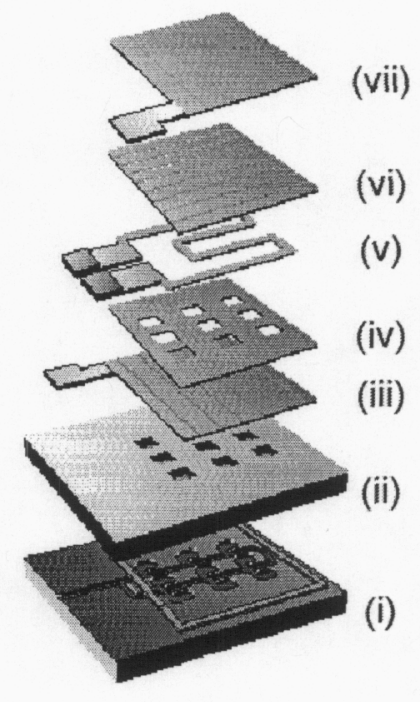

Figure 2. A schematic of the key structural components integral to the micro-fabricated fuel cell are the (i) micro-machined base manifold, (ii) thermal and electrical insulating layer, (iii) thin film anode, (iv) electrical insulating layer, (v) heater, (vi) electrolyte layer, and (vii) thin film cathode. 


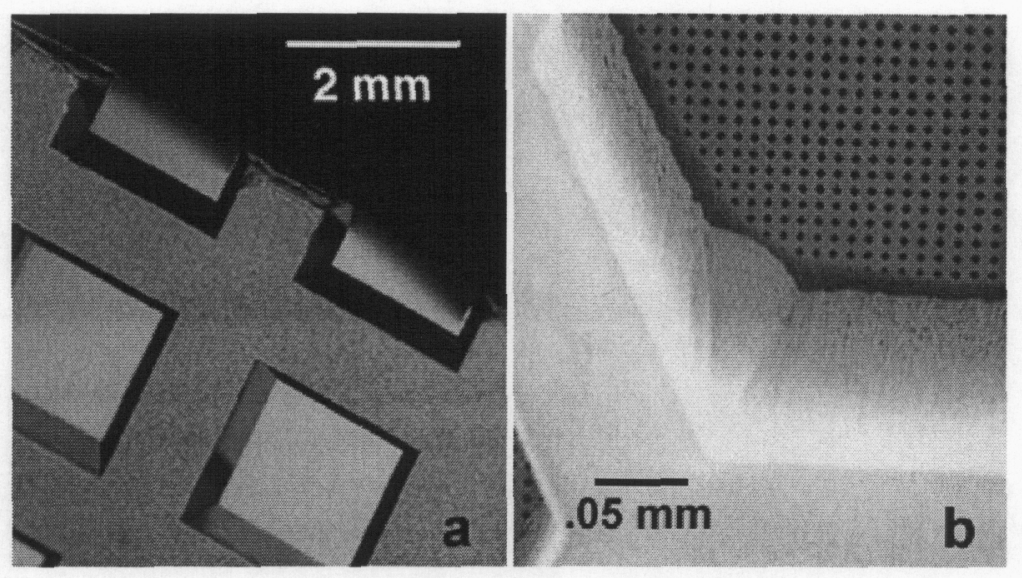

Figure 3. The use of photolithography and anisotropic etching facilitates the evolution of decreasing dimensions in the micro-machined base manifold from (a) $2 \mathrm{~mm}$ $\mathrm{x} 2 \mathrm{~mm}$ windows, to (b) a hexagonal frame with $5 \mu \mathrm{m} \times 5 \mu \mathrm{m}$ windows.

The physical vapor deposition processes to produce the electrodes within the anodeelectrolyte-cathode layer stack utilize two patterning methods - photolithography and hard masks. The sputter deposition chamber is evacuated to a base pressure less than $10^{-5} \mathrm{~Pa}$. The micro-machined silicon substrate is positioned $10 \mathrm{~cm}$ from an array planar magnetron sources. A 0.6-4.0 Pa working gas pressure of Ar at a flow of $30-40 \mathrm{~cm}^{3}-\mathrm{m}^{-1}$ is used during sputter deposition. The deposition begins by sputtering the electrode metal target, as e.g. nickel for the anode and silver for the cathode, at a $4-7 \mathrm{~W}-\mathrm{cm}^{-2}$ forward power to yield a layer thickness of 0.5 $5 \mu \mathrm{m}$. For photolithographic patterning, the electrode metals are deposited at room temperature to produce a dense and fine-grained columnar structure.[3,5] After the anode deposition, pores are formed in the layer via a photoresist mask. The pores are passages for gas flow to the electrolyte and control the area of the catalyst-electrolyte interface. The photolithographic pattern yields 3-5 $\mu \mathrm{m}$ diameter holes with a $3 \mu \mathrm{m}$ intermediate spacing. After developing the photoresist to form the template, the pattern is then etched into the Ni layer. The etching procedure utilizes $\mathrm{H}_{2} \mathrm{O}: \mathrm{HNO}_{3}(20: 1)$ at $45^{\circ} \mathrm{C}$ to produce an etch rate of $0.1 \mu \mathrm{m}-\mathrm{m}^{-1}$. The thin nitride windows are then removed by reactive-ion etching to expose the anode-electrolyte interface. For the hard mask method, the electrode metal is directly deposited with an inherent continuous porosity. The hard mask is used to define the boundaries of the deposit. The asdeposited porosity is produced by sputtering the metal with a raised working gas pressure while heating the substrate to $45-55 \%$ of the melt temperature of the electrode metal. The results of this novel deposition process are shown in scanning electron micrographs for nickel and silver (in Fig. 4). The elevated temperature and gas pressure enhance both incident scattering to the
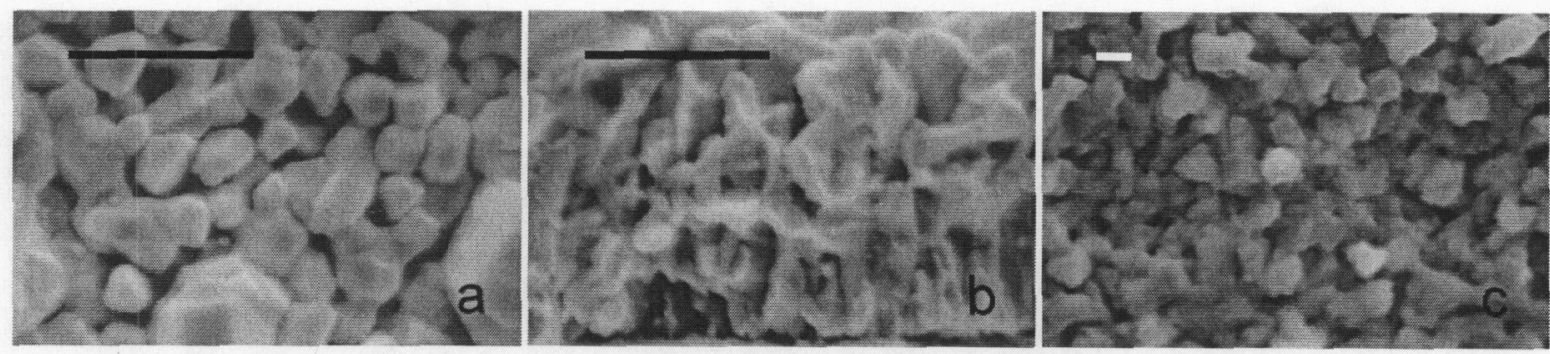

Figure 4. A porous electrode structure is imaged as sputter deposited in films of (a) nickel - in plan view, (b) nickel - in cross-section, and (c) silver - in plan view. $($ Bar $=1 \mu \mathrm{m}$.) 


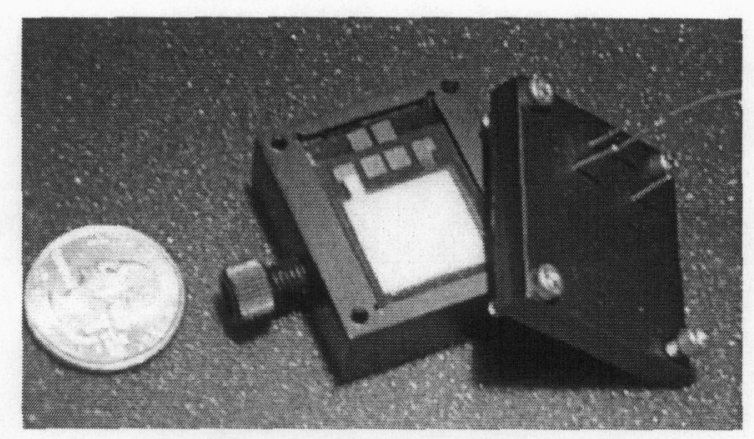

Figure 5. The micro-fabricated PEM and fuel cell package is shown with an integrated heater assembly, a thin-film fuel cell module, the electrical pin-contact leads, and the manifold structure.

substrate surface and ensuing surface mobility. This deposition condition favors recrystallization of the metal and forms bridges between the columnar structure yielding the morphology of a metallic sponge. The resultant electrode structure provides a path for electrical conductivity while the porosity enables the diffusion of reaction product species to sustain the generation of electrical current. The deposition of the electrodes sandwiches the electrolyte layer. For SOFCs, a thin $(10-50 \mathrm{~nm})$ electrode-electrolyte interface layer can be added through co-sputtering.

\section{TESTING \& ANALYSIS}

The PEM and SOFC are tested in similar ways. The fuel cell package to test a PEM cell (as shown in Fig. 5) consists of an integrated heater assembly, a thin-film fuel cell module, electrical pin-contacts to the electrodes, and the manifold structure for fuel supply. The major difference for the SOFC is that more refractory materials are used, i.e. stainless steel as compared to the plastic housing for the PEM cell, and that an external furnace heater can be used for high test temperatures. The fuel cell current is measured as the voltage is incrementally loaded using a semiconductor parameter analyzer. Air or an Ar- $20 \% \mathrm{O}_{2}$ gas mixture is supplied to the cathode and a humidified $\mathrm{Ar}-4 \% \mathrm{H}_{2}$ gas mixture is supplied as the fuel to the anode at a $2-6 \mathrm{~cm}^{3}-\mathrm{m}^{-1}$ flow rate. A backflow pressure up to $0.010 \mathrm{~atm}$, i.e. an equivalent to $10 \mathrm{~cm}$ of liq. $\mathrm{H}_{2} \mathrm{O}$, is applied to the anode side. A thermocouple is placed in contact with the manifold structure to measure the test temperature. Results for micro-fabricated PEM and SOFC (as shown in Fig. 6) yield current-
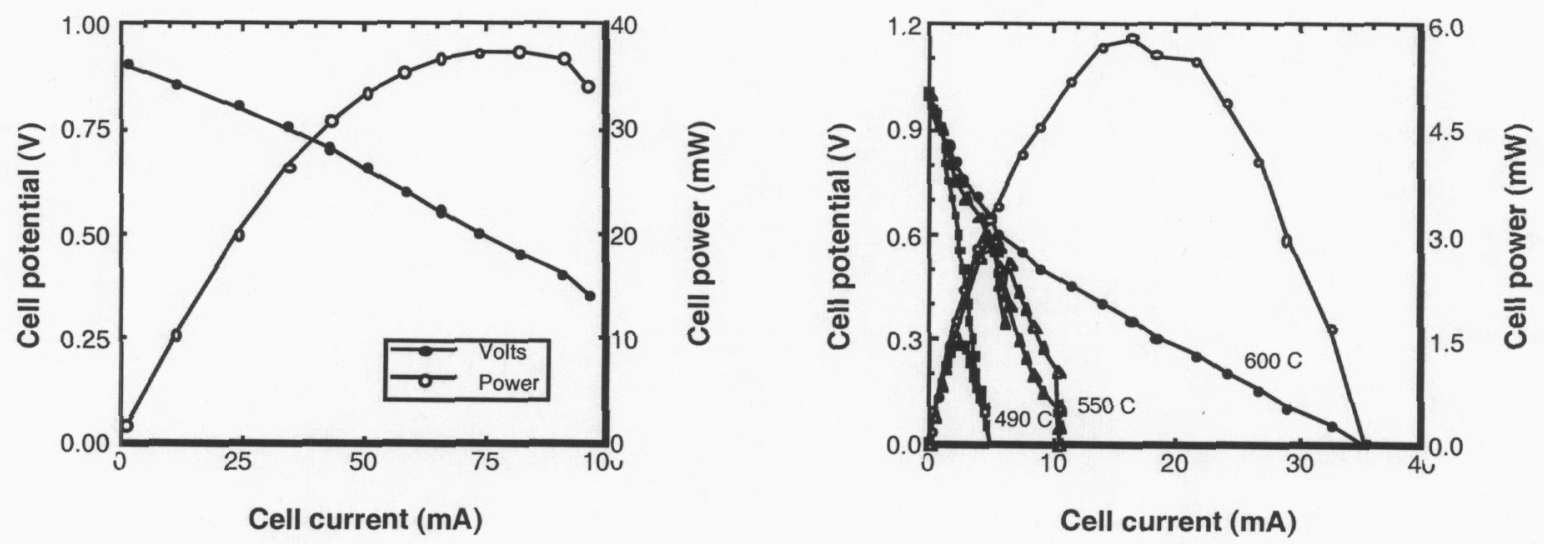

Figure 6. The current-voltage-power output of micro-fabricated PEM (left) and SOFC (right).

Table I. Peak power $\left(\mathrm{mW}-\mathrm{cm}^{-2}\right)$ of a micro-fabricated SOFC at test temperature $\left({ }^{\circ} \mathrm{C}\right)$

\begin{tabular}{|l|l|l|l|l|l|}
\hline Test Temperature $\left({ }^{\circ} \mathbf{C}\right)$ & 390 & 450 & 490 & 550 & 600 \\
\hline
\end{tabular}




\begin{tabular}{|c|c|c|c|c|c|}
\hline Cell Potential (V) & 0.60 & 0.60 & 0.55 & 0.55 & 0.35 \\
\hline Power Ouput (mW-cm $\left.{ }^{-2}\right)$ & 6 & 19 & 36 & 73 & 145 \\
\hline
\end{tabular}

voltage-power outputs representative of the component materials as typically used in bulk designs. The PEM cell is tested at $40{ }^{\circ} \mathrm{C}$ by applying a $6 \mathrm{~V}$ potential to the integrated $\mathrm{Pt}$ heater. The open-circuit voltage (OCV) for this cell is $0.9 \mathrm{~V}$. The electrodes form a $1 \mathrm{~cm} \times 1 \mathrm{~cm}$ area of contact to the polymer electrolyte. This PEM cell yields a computed peak power of $37 \mathrm{~mW}-\mathrm{cm}^{-2}$ at a cell potential of $0.45 \mathrm{~V}$ under these test conditions. The power output remains stable after 2 days of continuous operation. The SOFC yields an OCV of $1.0 \mathrm{~V}$ for the test temperatures up to $600{ }^{\circ} \mathrm{C}$. This fuel cell is only $2.5 \mu \mathrm{m}$ thick and is composed of a $0.5 \mu \mathrm{m}$ thick nickel anode, a 1.2 $\mu \mathrm{m}$ thick yttria-stabilized zirconia electrolyte, and a $0.8 \mu \mathrm{m}$ thick silver cathode. The electrodes form a $2 \mathrm{~mm} \times 2 \mathrm{~mm}$ contact area to the electrolyte. This SOFC yields a computed peak power of $145 \mathrm{~mW}-\mathrm{cm}^{-2}$ at a cell potential of $0.35 \mathrm{~V}$ under these test conditions. A summary of the computed output at intermediate temperatures is listed in Table 1. This cell was operated only once with 10 min. dwell times at each test temperature.

\section{SUMMARY}

Thin film and micro-electro mechanical machining technologies are combined to microfabricate miniature thin-film fuel cells. A silicon modular design serves as the platform for fuel cells based on either proton-exchange or solid-oxide membranes. Packaged devices are demonstrated using a hydrogen gas fuel supply with power outputs up to $0.15 \mathrm{~W}-\mathrm{cm}^{-2}$. The advent of micro-fabricated thin-film fuel cells offers a new solution for portable power requirements.

\section{ACKNOWLEDGMENTS}

This work was performed under the auspices of the U.S. Department of Energy by University of California, Lawrence Livermore National Laboratory under contract No. W-7405-Eng-48.

\section{REFERENCES}

1. A.F. Jankowski, in Ionic and Mixed Conducting Ceramics III, edited by T. Ramanarayanan, (Electrochem. Soc. Proc. 97-24, Pennington, PA, 1998) pp. 106-113.

2. A.F. Jankowski and J.D. Morse, in Materials for Electrochemical Energy Storage and Conversion II, edited by D. Doughty, D. Ginley, B. Scrosati, T. Takamura and Z. Zhang, (Mater. Res. Soc. Symp. Proc. 496, Pittsburgh, PA, 1998) pp. 155-158.

3. A. Jankowski, T. Graff, J. Hayes, and J. Morse, in Solid Oxide Fuel Cells VI, edited by S. Singhal and M. Dokiya, (Electrochem. Soc. Proc. 99-19, Pennington, PA, 1999) pp. 932-937.

4. J. Morse, A.F. Jankowski, R.T. Graff, and J. Hayes, J. Vac. Sci. Technol. A 18, 2003 (2000).

5. J. Morse, R. Graff, J. Hayes, and A. Jankowski, in New Materials for Batteries and Fuel Cells, edited by D. Doughty, H. Brack, K. Naoi, L. Nazar, (Mater. Res. Soc. Symp. Proc. 575, Pittsburgh, PA, 2000) pp. 321-324. 